al-Ihkam: Jurnal Hukum dan Pranata Sosial, 16 (2), 2021: 421-449

ISSN: 1907-591X, E-ISSN: 2442-3084

DOI: http://doi.org/10.19105/al-lhkam.v16i2.5250

\title{
Changes in Congregational Prayer Practices During the Covid-19 Pandemic in Aceh from Maqashid al-Sharia Perspective
}

\author{
Salman Abdul Muthalib \\ Universitas Islam Negeri Ar-Raniry, Banda Aceh \\ Jl. Syekh Abdul Rauf Darussalam Banda Aceh \\ Email:salman@ar-raniry.ac.id \\ Tarmizi M. Jakfar \\ Universitas Islam Negeri Ar-Raniry, Banda Aceh \\ Jl. Syekh Abdul Rauf Darussalam Banda Aceh \\ Email:tarmizi@ar-raniry.ac.id \\ Muhammad Maulana \\ Universitas Islam Negeri Ar-Raniry, Banda Aceh \\ Jl. Syekh Abdul Rauf Darussalam Banda Aceh \\ Email:muhammad.maulana@ar-raniry.ac.id \\ Lukman Hakim \\ Universitas Islam Negeri Ar-Raniry, Banda Aceh \\ Jl. Syekh Abdul Rauf Darussalam Banda Aceh \\ Email: lukmanhakim@ar-raniry.ac.id
}

Article history: Received: October 15, 2021, Accepted: December 15, 2021, Published: December 31, 2021

\begin{abstract}
:
Covid-19 has changed the habits of almost all activities of human life, including religious matters. The worship practices have also changed, such as performing prayers at home, keeping distant rows, and wearing masks. This paper is empirical legal research that seeks to examine the living law in the Aceh society with a maqashid shari'a perpective during a pandemic. The data collection techniques were interview, observation, and document study. It concludes that the
\end{abstract}

Author correspondence email: salman@ar-raniry.ac.id

Available online at: http:/ / ejournal.iainmadura.ac.id/index.php/alihkam/

Copyright (c) 2021 by al-ihkam. All Right Reserved 
government policies, including the 2020 Large-Scale Social Restrictions (PSBB), the 2021 Implementation of Community Activity Restrictions (PPKM), fatwas of Indonesian Ulema Council (MUI) and Tausiyah of Acehnese Ulema regulating and calling for restrictions on religious activities are rules with benefit values and in accordance with the principle of maqasid al-shari'a. Despite some people's rejection, the policies are, in fact, based on maqasid al-shari'a, namely protecting the life (hifz al-nafs) so that people will not get infected by the virus. Moreover, public safety is the highest law purpose to maintain. The policies also prove the state's role through the rule when conditions endanger the community in addition to avoiding harms as a part of Islamic law orders.

\title{
Keywords:
}

Covid-19; Worship Practices; Islamic Law; Maqashid

\begin{abstract}
:
Covid-19 telah mengubah kebiasaan hampir seluruh aktivitas kehidupan manusia, mulai dari ekonomi, sosial, budaya, pendidikan bahkan agama. Pada aspek agama aktivitas ibadah juga mengalami perubahan misalnya himbauan shalat di rumah, menjaga jarak saf dan memakai masker. Tulisan ini merupakan penelitian hukum empiris yang berupaya menelaah hukum sebagaimana yang terjadi dalam realitas masyarakat dengan pendekatan hukum Islam saat pandemi. Sedangkan teknik pengumpulan data yang dipakai adalah wawancara, observasi dan studi dokumen. Kajian ini menyimpulkan bahwa pada awalnya himbauan sebagai pemerintah tidak secara menyeluruh diikuti oleh masyarakat karena setiap daerah berbeda tingkat penularan dan kondisi covid terjadi. Setelah aturan PPKM 2021 diterapkan hal ini relatif teratur termasuk di Aceh karena dibedakan empat level dan berdasarkan tingkat penularan dan korban yaitu, merah, orange, kuning dan hijau. Kebijakan pemerintah agar tidak salat jamaah di masjid pada saat kondisi penularannya tinggi sebenarnya mengacu pada konsep maqashid syari'ah yaitu menjaga jiwa (hifz al-nafs) agar masyarakat tidak tertular virus. Meskipun sebagian masyarakat khusus daerah atau kabupaten yang tingkat penularannya rendah menganggap bahwa shalat berjamaah di masjid tetap harus dilakukan dengan pertimbangan menjaga agama (hifz al-
\end{abstract}


din) sesuai protokol kesehatan. Namun patut dicatat kebijakan pemerintah tersebut mengandung kemaslahatan yang bertujuan untuk menghindari kemudharatan dan menolak bahaya sebagaimana disebutkan dalam kaidah fikih. Sehingga menghindarkan diri dari kemudharatan dan taat kepada pemerintah juga merupakan perintah syariat Islam.

\section{Keywords:}

Covid-19; Praktik Ibadah; Hukum Islam; Maqashid

\section{Introduction}

Covid-19 that hits hard the whole world has changed several orders and activities of human life ranging from social, economic, cultural, educational, to religious issues. ${ }^{1}$ In religion, various legal issues have arisen related to Covid-19, such as the legal status of vaccines. ${ }^{2}$ Additionally, due to the Pandemic, some worships have different procedures from the normal rules that make some Muslims doubt the validity of the new worship practices. This phenomenon has invited the pros and cons among the public and ulemas (Islamic scholars). ${ }^{3}$

Along with it, as an early attempt to handle the Pandemic, the Indonesian Government had issued a regulation, namely

${ }^{1}$ Muhammad Kumaidi and Evi Febriani, 'Implementasi Kaidah La Yunkiru Tagayyur Al-Ahkam Bitagayyur Al-Azman Wa Al-Ahwal Dalam Ibadah Di Masa Pandemi', Asas: Jurnal Politik, Hukum Dan Ekonomi Islam, 12 (1) (2020), 64-81. Shubhan Shodiq, 'Penanganan Covid-19 Dalam Pendekatan Fikih Dan Ushul Fikih: Analisis Kebijakan Pembatasan Sosial Berskala Besar Di Bidang Keagamaan', Al-Adalah, 5, (2) (2020), 113-34.

${ }^{2}$ Asrorun Ni'am Sholeh, 'Toward a Progressive Fatwa: MUI's Response to the Covid-19 Pandemic', Ahkam, 20, No. 2 (2020), 281-98. Asrorun Ni'am Sholeh and Muhammad Ishar Helmi, 'The Covid-19 Vaccination: Realization on Halal Vaccines for Benefits', Samarah, 5, No. 1 (2021), 171-90.

3Prita Priantini NC. Jujun Junaedi, Mukhlis Aliyudin, Dede Sutisna, 'Konflik Interpretasi Fatwa MUI Dalam Pelaksanaan Ibadah Selama Pandemi Covid-19', Al-Tadabbur: Jurnal Kajian Sosial, Peradaban Dan Agama, 6, No. 2, (2020), 175-189. S. Samsuduha, 'Masalah Kebijakan Pencegahan Wabah Pandemi Covid-19 Dalam Islam', Jurnal Al-Tafaqquh, 1, No. 2 (2020), 117-27. 
Government Regulation (PP; Peraturan Pemerintah) No. 21 of 2020 concerning Large-Scale Social Restrictions (PSBB; Pembatasan Sosial Berskala Besar). The regulation restricts social activities related to school and workplace settings, religious activities, and public facilities. In addition, fatwas (ruling of Islamic law) of the Indonesian Ulema Council (MUI; Majelis Ulama Indonesia) No. 14 of 2020 were also issued regarding the procedures for worship during the Pandemic. ${ }^{4}$ Particularly in Aceh, there issued Circular Letter of the Governor of Aceh No. 440/4820 2020 as well as the Recommendations of the Muzakarah (exchange of thoughts) of Acehnese Charismatic Ulemas initiated by the Aceh Ulema Consultative Assembly (Majelis Permusyawaratan Ulama/MPU, like the MUI) in August 2020.5

Since the Covid-19 outbreak at the end of 2019 until August 18, 2021, the number of Covid-19 cases in Aceh has reached 28,547 cases. Of these, 21,521 cases were cured, 1,212 were death cases, and 5,814 are still being treated. ${ }^{6}$ The spike in Covid-19 cases has caused the Aceh Government and ulema institutions to issue several rules to reduce the outbreak ranging from regulations related to worship procedures, restrictions on opening coffee shops, closures of tourist sites, rearrangements of working hours for civil servants, maintenance of health protocols, preparation of health facilities, and recitation of qunoot nazilah. ${ }^{7}$

The government regulations, MUI fatwas, and Aceh MPU recommendations are deemed as necessary steps in accordance with

${ }^{4}$ Government Regulation Number 21 of 2020 on Large-Scale Social Restrictions in the Context of Accelerating the Handling of Corona Virus WRUS Disease 2019 (Covid-Ig). https://jdih.setkab.go.id/PUUdoc/ 176085 /PP_Nomor_21_Tahun_2020.pdf. Fatwa MUI No 14 tahun 2020 tentang Penyelenggaraan Ibadah dalam Situasi Terjadi Wabah Covid-19, https://mui.or.id/berita/27674.

${ }^{5}$ Circular Letter of the Governor No. 440/4820 of 2020. https://ppid.acehprov.go.id/assets/uploads/31E1/informasipublik/qSbI/ Surat_Edaran_Gubernur_Aceh.pdf.https://aceh.antaranews.com/berita/16 1406/ulama-kharismatik-aceh-lahirkan-rekomendasi-penanganan-covid-19. ${ }^{6}$ https://covid19.acehprov.go.id.

${ }^{7}$ Circular Letter of the Governor No. 061.2/7309 of 2021. https://jdih.acehprov.go.id/dih/detail. 
Islamic law to maintain the main objectives of religion (al-dharuriyat al-khams). Therefore, the newly determined way to practice worship is also considered an effort to minimize virus transmission. ${ }^{8}$ In this regard, the main argument in the government policies related to Covid-19, which implicates the changing of worship, is based on the benefit aspect as viewed from the maqasid al-shari'a. In this context, maqasid al-shari'a, which prioritizes benefit, is an effort to protect human life (hifz nafs) from harm or the danger of viruses.

The regulations, mainly relating to worship practice, are in accordance with Islamic law under certain situations and conditions ${ }^{9}$, and as a consequence, they temporarily cause some changes in worship practices. The aim is to provide benefits and maintain the safety of people despite some people having discomfort while performing worshipping in a new way. As one of the areas affected by Covid-19, Acehnese is supposed to follow the rules and policies. However, some people disagree and disobey regulations that restrict congregational prayers at mosques, set up distant rows, and oblige mask-wearing during prayers. The reason that their worship will not be perfect and even invalid is that these applied rules are not in accordance with religious teachings. The effort to limit worship activities is a part of measures to protect people from the dangers of the virus. This contains benefits in accordance with the main objectives of Islamic law or maqasid al-shari'a, which is hifz al-nafs.

In light of these explanations, it can be understood that the government policies and the MUI Fatwa followed by the Aceh Governor's Circular Letter and Recommendation of the Acehnese Charismatic Ulama Muzakarah on worship practices during the Pandemic have not been discussed in-depth, let alone linked to the government policies. Thus, this study finds it necessary to describe some information on how the Acehnese understand the procedures for Islamic worship in unusual circumstances. This study focuses on three problems: first, a review of Islamic law on the practices of

${ }^{8}$ Hudzaifah Achmad Qotadah, 'Covid-19: Tinjauan Maqasid AlShariah Terhadap Penangguhan Pelaksanaan Ibadah Shalat Di Tempat Ibadah (Hifdz Al-Nafs Lebih Utama Dari Hifdz Al-Din?)', Salam: Jurnal Sosial \& Budaya Syar-I, 7, No. 7 (2020), 659-672.

${ }^{9}$ Muhammad Kumaidi and Evi Febriani. 
congregational prayers during the Covid-19 Pandemic in Aceh; Second, changes and dynamics of congregational prayer practices in the time of Covid; and third, three perspectives of maqasid al-shari'a on the government policies during the Covid-19 Pandemic. In short, the study aims to examine changes in the practices of congregational prayers within Acehnese society during the Covid-19 Pandemic from the perspective of maqasid al-shari' $a$.

The government policies that regulate prayer activities are an important theme in this study. To date, research has been carried out on changes in prayers and other worship practices during the Covid19 period. Junaedi et al. discussed the MUI fatwa No. 14 of 2020 regarding worship practices during the Pandemic, including recommendations for observing health protocols. They mentioned that this fatwa was made based on the purpose of maqasid al-shari'a, which is for the benefit and protection of the community instead of negating worship. ${ }^{10}$ Another research by Sirajuddin et al. examined the Circular Letter of the Governor of South Sulawesi regarding the abolition of Friday prayers in accordance with Islamic law, namely maqasid al-shari'a, which puts the benefit of mankind as the main principle. ${ }^{11}$

Next, research by Arsad investigated the effectiveness of rukhsah (exception law) in carrying out worship during the Covid-19 Pandemic. He explained that the use of rukhshah in worship had already been implemented in society, such as congregational prayers in mosques with spaced rows, no physical contact as well as the special treatment of the deceased. ${ }^{12}$ Meanwhile, Syandri and Akbar concluded that the use of masks in prayers is allowed during unusual circumstances to prevent the virus from spreading, although the original law of wearing a mouth cover is makruh (the avoidance of

\footnotetext{
${ }^{10}$ Jujun Junaedi, Mukhlis Aliyudin, Dede Sutisna.

11 Abdul Wahid Haddade Sirajuddin, Kasjim Salenda, 'Peniadaan Shalat Jumat Dalam Surat Edaran Gubernur Sulsel Nomor: 451.11/2057/2020 Selama Pandemi Covid-19 Perspektif Maqasid AlSyariah.', Nukhbatul 'Ulum: Jurnal Bidang Kajian Islam, 6 (2) (2020), 289-309.

${ }^{12}$ Muhammad Arsad Nasution, 'Efektivitas Rukhshah Dalam Pelaksanaan Ibadah Masa Pandemi Covid-19', Yurisprudentia: Jurnal Hukum Ekonomi, 6, No. 1 (2020), 59-74.
} 
which yields merit but the performance of which is not sinful) and does not invalidate the prayer. ${ }^{13}$ Another study by Qotadah also explained that protecting life is more important in the Covid-19 condition as emphasized by maqasid al-shari'a; thus, restrictions, suspensions, and temporary prohibitions on the implementation of worship are policies that follow the Islamic law. ${ }^{14}$ On a similar note, Shodiq (2020) concluded that restrictions on worship during Pandemic are not against Islamic law because in Islamic law, protecting life holds more importance than protecting property. ${ }^{15}$ Similarly, Samsuduha described that the government policies in preventing and handling Covid-19 have a beneficial aspect, which is to maintain one's life and offspring. ${ }^{16}$

Some of the aforementioned studies have discussed the practices of worship, especially prayers, during the Covid-19 period in Indonesia. However, they were normative legal studies or literature studies based on legal rules, articles, and media reports regarding worship practices during the pandemic period. This present study, however, in addition to using document study, also conducted interviews and observation to collect the data needed.

\section{Method}

This study used empirical legal research that seeks to examine the law as it lives in the real life of society. ${ }^{17}$ Data were collected by means of interviews, observation, and document study. Interview with ulemas, academics, community leaders, mosque administrators, and same members of the community. Observation aimed to examine the legal facts in the community so that the study could illustrate the level of understanding of the procedures for carrying out worship during the Pandemic in Acehnese society. Further, a document study

13 Syandri dan Fadlan Akbar, 'Penggunaan Masker Penutup Wajah Saat Shalat Sebagai Langkah Pencegahan Wabah Coronavirus Covid-19.', Salam: Jurnal Sosial \& Budaya Syar-I, 7, No. 3 (2020), 261-268.

${ }^{14}$ Hudzaifah Achmad Qotadah.

${ }^{15}$ Shubhan Shodiq.

${ }^{16}$ Hudzaifah Achmad Qotadah.S. Samsuduha.

${ }^{17}$ Jonaedi Efendi and Johnny Ibrahim, Metode Penelitian Hukum:Normatif Dan Empiris (Jakarta: Kencana, 2016). Zainuddin Ali, Metode PenelitianHukum (Jakarta: Sinar Grafika, 2014). 
was used to collect data related to the government regulations or policies on the procedures for carrying out worship.

The study utilized the approach and analysis based on Islamic law. ${ }^{18}$ The results of the interview, observation, and document study were then analyzed from the perspective of maqasid al-shari'a as social reality in the form of worship practices during the Pandemic cannot be separated from the point of view of Islamic law. Specifically, this study used maqasid al-shar'ia, rukhsah, dar'u al-mafasid and obedience to the government in terms of the theories or approaches of Islamic law.

The first theory is maqasid al-shari'a (the objectives of sharia) or also referred to as the secrets set by Allah in every law. ${ }^{19}$ The objectives predetermined by Allah and the Messenger, according to this theory, are for the benefits of mankind as sharia is regulated to achieve such purposes either directly or indirectly. Thus, it can be ascertained that all laws stipulated and formulated must contain benefits, although sometimes they cannot be clearly comprehended. Understanding maqasid al-shari' $a$ is deemed necessary for everyone, especially mujtahids (expert in Muslim Law) who seek to explore the laws from the texts of the Qur'an and the Prophet's hadith, ${ }^{20}$ in order the results of their ijtihad (independent reasoning) in accordance with the objectives of the sharia. To ensure an objective of the sharia, ulemas have arranged several requirements, including that the objectives of the sharia must be fixed, clear, and measurable. ${ }^{21}$

The maslahah (the best choice in Islamic Law) that the sharia aims to achieve is classified into three categories. Firstly, the maslahah daruriyyat or primary benefits essential to human life are related to both the world and the hereafter. If such a maslahah is neglected, it will disrupt and create chaos in the order of human life. This category has five elements: the maintenance of religion, life, mind, offspring,

18Juhaya S. Praja, Teori Hukum Dan Aplikasinya (Bandung: Pustaka Setia, 2014).

${ }^{19}$ Wahbah Al-Zuhayli, Usul Al-Figh Al-Islami, Juz 2 (2nd Ed.) (Damaskus: Dar al-Fikr, 2004).

${ }^{20}$ Thahir Ibn 'Asyur, Maqasid Al-Syari'ah Al-Islamiyyah (1st Ed.) (Tunisia: Al-Faniyyah). p. 11-12.

${ }^{21}$ Al-Zuhayli, Usul Al-Figh Al-Islami, Juz 2 (2nd Ed.). p. 1047 
and wealth. This category is the most vital one to take care of in order to maintain the continuity of human life. ${ }^{22}$ Secondly, the maslahah hajiyyat or secondary benefits. This maslahah is necessary to relieve difficulties in life. If this is neglected, it will not impede human life but rather cause hardship and trouble. For example, leniency allows for travelers to shorten (qasar) prayers and the sick may be allowed to not fast. Thirdly, maslahah tahsiniyyat or tertiarty benefits which serve as a complement in one's life, such as wearing presentable clothes in prayers and wearing fragrances when going to the mosque. Yet, if this is ignored, it will not interfere with their lives.

The second theory, rukhsah (exception law), is a part of the given law $\left(w a d h^{\prime} i\right)$ in Islam, which is defined as leniency or concession provided by religion to a Muslim under certain conditions. ${ }^{23}$ Allah's specific provisions are based on certain obstacles or hardships in order to protect their people's needs without eliminating the basic law. ${ }^{24}$ The concessions in Islam include procedures for worship in a certain situation, such as the permissibility of combining two prayers at one time (jama') and the permissibility of qasar prayers for travelers. ${ }^{25}$ In addition, other forms of concessions for sick people are abolition on the obligation of Friday and congregational prayers. If a person is ill and finds it difficult to perform those two prayers or is worried that his/her pain will elevate if he/she prays at the mosque, ${ }^{26}$ it is permissible to pray at home and leave the congregation. This situation was experienced by the Prophet Muhammad when he was ill, in which he requested Abu Bakr to change his position as imam (leader) of the prayers at the

${ }^{22}$ Abdul Wahab al-Khallaf, Ilmu Ushul Figh (12th Ed.) (Kuwait: Dar alQalam, 1978).

${ }^{23}$ Mahmudin, 'Rukhsah (Keringanan) Bagi Orang Sakit Dalam

Perspektif Hukum Islam', Jurnal Ilmiah Al Qalam, 11 (23) (2017), 65-85.

24 Al-Zuhayli, Usul Al-Figh Al-Islami, Juz 2 (2nd Ed.). p. 108

25 Mahmud Syaltut, Al-Islam 'Aqidah Wa Syari'ah (3rd Ed). (Dar alQalam, 1996).

${ }^{26}$ Mahmudin. 
mosque even though the Prophet's residence was situated very close to the mosque. ${ }^{27}$

The third theory, dar'u al-mafasid (resisting any damage), is one of the concepts in Islamic law which aims to prevent damage. Islamic law assesses that efforts to stay away from things that can lead to damage or harm are better than doing those that bring benefit. In other words, leaving out a prohibition is more important than carrying out obligations. ${ }^{28}$ This concept is applied to certain cases as an effort to prevent the spread of harm in society so that people can avoid difficulties and will eventually be benefited. ${ }^{29}$ One of the basic arguments of ulemas in formulating this concept is the hadith of the Prophet, which reads:

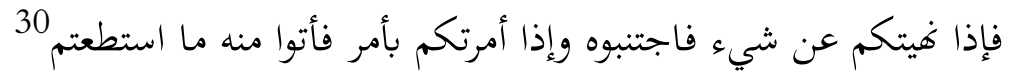

What I have forbidden for you, avoid. What I have ordered you [to do], do as much of it as you can.

It implies that doing a good deed in Islam will remain applicable if the circumstances allow and as long as there is no negative impact that can interfere Muslims. However, if conditions change and doing good will harm someone, then Islam strictly forbids this deed. ${ }^{31}$

The fourth theory is obedience to the Government or, in this case, the ruling leaders who control society. Islam suggests that society needs to obey their leaders who take care of various interests for their lives so that the order of life can work well in an orderly manner. This also implies that a leader is a person who commands

\footnotetext{
${ }^{27}$ Muhammad bin Idris Al-Syafi'i, Al-Umm Vol. 1 (Beirut: Dar alMa'rifah, 1973). Zakariya Ali Yusuf Al-Syirazi, Al-Muhadhdhab Fi Figh AlImam Al-Syafi'i (Beirut: Dar al-Ma'rifah).p. 101.

${ }^{28}$ Ali Hasballah, Usul Al-Tasyri' Al-Islami (Cairo: Dar al-Ma'arif).

${ }^{29}$ Adib Hamzawi, 'Qawa'id Usuliyyah \& Qawa'id Fiqhiyyah (Melacak Konstruksi Metodologi Istinbath Al-Ahkam)', Inovatif, 2, No. 2 (2016), 104.

${ }_{30}$ Muhammad ibn Ismail Al-Bukhari, Sahih Al-Bukhari, Vol. 6. (Beirut: Dar Ibn Katsir, 1987).

${ }^{31}$ Fahmi Hasan Nugroho Ayi Yunus Rusyana, Dedi Supriyadi, Ali Khosim, 'Fatwa Penyelenggaran Ibadah Di Saat Pandemi Covid-19 Di Indonesia Dan Mesir', Digital Library UIN Sunan Gunung Djati, 2020, 5.
} 
goodness and forbids evil. ${ }^{32}$ Leaders have an important position in Islam in directing the society, whether related to social, political, religious, or other matters. Islam has set the obligation of obedience to a leader as long as he/she does not invite disobedience to Allah. ${ }^{33}$

Obedience and compliance to the Government is, therefore, a part of Islamic teachings. This compliance is not only limited to religious matters but also to various matters regulated by the Government. ${ }^{34}$ Moreover, Islam regulates not only the relationship between humans and God but also between humans and their environment. ${ }^{35}$ In terms of obedience to the leader, Islam gives the rights for leaders that society needs to fulfill. Among their rights are getting the prayer from people, to be respected and honored, as well as getting their orders obeyed as long as they are not involved in disobedience. ${ }^{36}$

\section{Discussion and Result}

Changes in Performing Prayers during the Covid-19 Period in Aceh a. Suggestions for Praying at Home during the Pandemic

The Covid-19 outbreak in Indonesia has prompted the Government to issue several rules to prevent the wider spread of the virus.37 Among the regulations is the issuance of government

32Khairunnas Jamal and Kadarusman., 'Terminologi Pemimpin Dalam Alqur'an (Studi Analisis Makna Ulil Amri Dalam Kajian Tafsir Tematik)', An-Nida': Jurnal Pemikiran Islam, 39, No. 1 (2014), 127.

33 Jumratul Mubibah and Ummul Faizah Sulaiman Kurdi, 'Konsep Taat Kepada Pemimpin (Ulil Amri) Di Dalam Surah an-Nisa : 59, Al-Anfal :46 Dan Al-Maidah : 48-49 (Analisis Tafsir Al-Qurthubi, Al-Mishbah, Dan Ibnu Katsir', Journal of Islamic Law and Studies, 1, No. 1 (2017), 33-45.

34 Analiansyah, 'Ulil Amri Dan Kekuatan Produk Hukumnya (Kajian Terhadap Perspektif Teungku Dayah Salafi Aceh Besar).', Analisa, 21, No. 2 (2014), 269.

${ }^{35}$ Manna Khalil Al-Qattan, Al-Tasyri' Wa Al-Figh Fi Al-Islam: Tarikhan Wa Manhajan. , 1976, p. 10. (Maktabah Wahbah, 1976).

${ }^{36}$ Kaizal Bay, 'Pengertian Ulil Amri Dalam Al-Qur'an Dan Implementasinya Dalam Masyarakat Muslim', Jurnal Ushuluddin, 7, No. 1 (2011), 120.

${ }^{37}$ Imam Fahrudin, 'Pengguguran Kewajiban Shalat Berjama'ah Sebagai Upaya Pencegahan Penyebaran Covid-19', SALAM: Jurnal Sosial \& Budaya 
regulations such as PSBB/2020, PPKM/2021, and Circular Letter of the Minister of Religious Affairs, which prohibit citizens from gathering to avoid any crowd. Several prohibitions include congregation prayers in mosques, and as an alternative, Muslims are encouraged to worship individually or with their families at their respective homes. ${ }^{38}$

Fauzi Saleh, a member of the MPU of Banda Aceh City, explained that figh rule reading taghayyar al-Ahkam bi taghayyur alzaman wa al-makan (changes in the law occur because of changes in time and place) indicates that the law can alter due to changes in situations and places. Thus, having a change in the procedure for carrying out worship due to certain conditions is common thing. In this case, the concept of legal provisions in normal circumstances (azimah) has shifted to legal provisions with concessions (rukhsah). Saleh added that under the figh law, the condition of a person who performs prayer might change. In normal circumstances, one prays while standing up while in a weak state. One may do it while sitting or even lying down. Therefore, he concluded that there are no obstacles in practices of worship as long according to the circumstances, needs, and maslahah. ${ }^{39}$ Additionally, according to Imam Nawawi, Islamic law can make the obligation to perform Friday prayers invalid on the grounds of troublesome illness. ${ }^{40}$ Hence, the pandemic conditions that possibly endanger the community at large are more of a strong reason for not allowing Friday and congregational prayers. ${ }^{41}$

Furthermore, the MUI as an institution with authority to issue legal fatwas (No. 14 of 2020) has also promulgated a fatwa regarding the Implementation of Worship in the Situation of the Covid-19 Outbreak. The fatwa stipulates that in conditions of uncontrolled

Syar-I, 7, No. 10, (2020), 939-948.

${ }^{38}$ Circular Letter of the Minister of Religious Affairs No. 15 of 2020.

${ }^{39}$ 'Interview with Fauzi Saleh, Member of Banda Aceh MPU'

${ }^{40} \mathrm{Abu}$ Zakaria Yahya bin Syarf al-Nawawi, Al-Majmu' Syarh AlMuhadhdhab, Jilid IV (Dar al-Fikr, n.d).

41Sirajuddin, Kasjim Salenda, dan Abdul Wahid Haddade, ‘Peniadaan Salat Jumat Dalam Surat Edaran Gubernur Sulsel Nomor: 451.11/2057/2020 Selama Pandemi Covid-19 Perspektif Maqāșid AlSyarīah,"', NUKHBATUL 'ULUM: Jurnal Bidang Kajian Islam, 6 no. 2 (2020), 289-309. 
spread of the virus in any life-threatening area, Muslims are not allowed to hold Friday prayers until the situation returns to normal. As an alternative, it is obligatory to replace it with the dhuhur (noon) prayer at their respective homes. Likewise, it is also not permissible to hold worship activities that involve large numbers of people and are deemed as a possible epicenter for the spread of Covid-19 virus. It includes congregational five daily prayers, rawatib prayers, taraweeh prayers, and Eid al-Fitr or Eid al-Adha prayers in mosques or other public places as well as gathering for the mass Qur'anic recitations and majelis taklim (learning gathering). ${ }^{42}$

However, the MUI fatwa, as well as tausiyah, in the context of Islamic law, is non-binding and non-coercive which is slightly different from the Aceh MPU. Despite it, the consideration of the ulamas will usually be noticed by the Aceh government as part of the autonomy and privileges of Aceh regulated in Act No. 11 of 2006,43 particularly on matters of religion and Islamic law, as ulemas play a vital role in the life and development of Aceh.

Unfortunately, most Acehnese tend not to care about the regulation in performing their daily worship practices as they are still doing the same as in normal times. Some of them seem to have not been well educated about the practices of worship in unusual conditions and keep thinking that worship must still be done in a perfect form and therefore should not be made easy. In fact, in Islamic figh, several concepts ease Muslims to practice their religion or perform worship, 44 including when they are worried about certain conditions or risks to their health if they, for instance, keep doing prayers in the congregation such as Friday prayers. ${ }^{45}$ This concept is a reflection of the characteristics of Islamic law, which are universal, systematic, realistic, flexible, and not burdensome. ${ }^{46}$

42Fatwa MUI No 14 of 2020 on the Implementation of Worship in the Covid-19 Situation, https://mui.or.id/berita/27674

${ }^{43}$ Law Number 11 of 2006 on the Government of Aceh. https://pih.kemlu.go.id/files/UU\%2011-\%202006.pdf. Abidin Nurdin, Reposisi Peran Ulama dalam Pelaksanaan Syariat Islam di Aceh, Jurnal alQalam 18, No. 1 (2012), 54-65.

44.Muhammad Arsad Nasution.

${ }^{45}$ Mahmudin.

46Hendra Gunawan, 'Karakteristik Hukum Islam.', Jurnal Al-Maqasid, 4, 
Relating with this, Moch. Fajarul Falah, a member of the Aceh Province MPU, explained that in regards to the call for people to pray at home, it should be related to the Acehnese culture. In Aceh, such a case is very sensitive because people tend to think that the regulations are certain efforts to keep people away from worship. Therefore, he added that if Acehnese disagreed, it would be good to let them be. Therefore, Falah believed that there was no need to close the houses of worship as long as Muslims could comply with proper health protocols. ${ }^{47}$

The prohibition of performing congregational prayers at mosques and efforts to close mosques are furthermore considered a ploy to keep Muslims away from their religion. ${ }^{48}$ This assumption becomes exacerbated when some random information from social media says that various regulations issued by the Government were influenced by foreign interests. The unreliable information has further fueled people's rejection of the Government's appeal. Moreover, some ulemas have emerged to provide different information coming from the official Government that the controversy at the grass-root is inevitable.

In responding to the situation, the Aceh government has asked the ulemas to provide support to the Government in tackling the Pandemic and ensuring people comply with related regulations. On August 26, 2020, for instance, the Aceh Ulemas Muzakarah was held and resulted in several recommendations for mitigating Covid-19. Among the recommendations related to worship, the ulemas requested the Mosque Prosperity Bodies (Badan Kemakmuran Mesjid/BKM) to remind worshipers to always obey health protocols when carrying out Friday prayers, to limit the duration of the khutbah (sermon), and to recite qunoot nazilah at every five daily prayers. However, the recommendations do not work at all urging people to pray at home with their families.

Consequently, government regulations that urge people not to carry out worship in mosques are not very well obeyed by the

No. 2, (2018), 105-25.

${ }^{47}$ Interview with Moch. Fajarul Falah, Member of Aceh MPU, August 3, 2021.

${ }^{48}$ Hudzaifah Achmad Qotadah. 
community. In addition to religious sentiment, another reason is the low level of the transmission of Covid-19 in the early days of the Covid outbreak in Aceh. However, when many people were getting infected and passed away, people started to consciously not pray at the mosques or continue to pray but with rows far apart.

\section{b. Spacy Row Arrangement in Congregational Prayers}

Another suggestion issued to cope with the Covid-19 outbreak in Indonesia is the arrangement of rows in congregational prayers with distance. Before the Pandemic, rows were culturally set close according to Islamic teachings and based on the hadith of the Prophet Muhammad. The close arrangement is even considered as a part of prayers' perfection. However, during the Pandemic, the rows in congregational prayers are obliged to be spaced so that the distance between one person and those next to him/her is not too close. This is also a part of the compliance with the Government's program for social distancing, which is required in daily activities, including when performing worship or prayers. ${ }^{49}$

Regarding this, the Aceh Government urges worshipers to keep their distance in rows. During the Eid al-Fitr and Eid al-Adha prayers, the Indonesian National Armed Forces (TNI; Tentara Nasional Indonesia) through the Military District Command (Koramil or Komando Rayon Militer) also wrote to the BKM (Badan Kemakmuran Masjid or mosque administrator) to urge worshipers to wear masks while praying, keeping distance, bringing own prayer mats, and prohibit handshakes after the prayers as it usually becomes a habit. 50 This method seemed to be quite effective as all mosque administrators received the Government's message. Meanwhile, the Government also monitors the mosques to ensure compliance with the instruction by delegating civil servants and security forces from the sub-district police and Koramil.

However, based on several observations, only several mosques in Aceh obeyed the aforementioned instruction, especially the mosques under the supervision of the Government like mosques in

${ }^{49}$ Circular Letter of the Minister of Religious Affairs No. 15 of 2020

${ }^{50}$ Appeal of Koramil in Ulee Kareeng Subdistrict, Banda Aceh, on Eid al-Fitr 2021 
the TNI and the Indonesian National Police (Polri) compounds Baiturrahman Mosque and the Polda (Regional Police) Mosque. ${ }^{51}$ Other mosques ignored the rule and the process for performing worship still ran as usual without any distance among worshipers even though the emergency status had not been lifted by the Government.

They regard the instruction to keep distance in prayers, Moch. Fajarul Falah explained that according to legal principles, changes in worship procedures do not matter, including wearing masks in prayers and the distant space among worshipers. As long as the worshippers are still inside the mosque, he added, the prayers will be considered valid. Therefore, he mentioned that in this case, it is necessary to educate the public in order not to suffer anxiety because, in current conditions, health protocols must be maintained in all situations, including when performing prayers. As long as the changes do not violate the rules of sharia law, it does not become any problem. ${ }^{52}$

Nevertheless, Abdullah, a congregation member in Dayah Tanoh, Pidie District, said that the disobedience to maintain distance in prayer was because of a lack of understanding of the rules of closing rows. Some consider it as a necessity and consequently assume that without the close row, it is deemed the same as reducing rewards of congregational prayers. A few others even consider that their prayers invalid. ${ }^{53}$ In line with that Syukur Gade, a mosque congregation in Banda Aceh City, said that people who pray at the mosque by wearing masks and keeping their distance are part of the human effort to prevent the spread of Covid-19. While we are ordered by Allah to make efforts, so endeavor is part of religious teachings. ${ }^{54}$

${ }^{51}$ Observation result, around January-August 2021

${ }^{52}$ Interview with Moch. Fajarul Falah, Member of Aceh MPU, August 3, 2021

53Interview with Abdullah, a local of Pidie District, August 10, 2021

${ }^{54}$ Interview with Syukur Gade, a local of Banda Aceh City, August 12, 2021. 
This particular view refers to a hadith of the Prophet Muhammad, which is often recited by the imams when they are about to start the prayers, which reads:

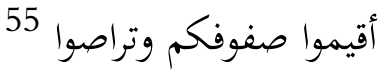

Meaning: Straighten your rows and stand closer together.

The community understands this hadith in a general context literally without relating it to certain situations and conditions regardless of when and how the context was when the Prophet delivered the hadith. In fact, according to the books of figh in the Shafi'i school, following the imam in congregational prayer with a distance of 3 zira' (about 1.5 meters) is considered valid. It goes the same with the distance among a worshiper and others his/her right or left. ${ }^{56}$ Imam Nawawi even stated that the distance between the imam and the worshippers and between one worshipper to another is 300 zira' (150 meters) as long as the worshippers know the imam's prayer and do not stand in front of him. ${ }^{57}$

The row arrangement as described above is valid under normal circumstances, let alone under certain conditions such as in the midst of a Pandemic with the big spread of the virus that endangers Muslims. Indeed, all ulemas agree that a tight and close row in prayers is better (afdhal) because it follows the guidance of the Prophet. However, considering the rule that rejecting harm is more important than seeking benefit, it can be concluded that avoiding the deadly virus by keeping a distance in prayer is more prioritized than getting the rewards of performing congregational prayers in the usual arrangement. The relevant principle of figh rule in this condition is rejecting harm which is taken precedence over seeking benefit (tark al-mafasid muqaddam ala jalbi al-masalih).

It is important to take a note, however, that although various government efforts continue to be made against non-compliance in

\footnotetext{
${ }^{55}$ Muhammad ibn Ismail al-Bukhari, Sahih Al-Bukhari, Vol. 1.

${ }^{56} \mathrm{Abdul}$ Karim Al-Rafi'i, Al-'Aziz Syarh Al-Wajiz, Vol. II (1st Ed.) (Beirut: Dar al-Kutub al-Ilmiyyah, 1977).

${ }^{57} \mathrm{Abu}$ Zakaria Yahya bin Syarf al-Nawawi, Al-Majmu' Syarh AlMuhadhdhab, Jilid IV, (Dar al-Fikr, n.d.). p. 303-305.
} 
maintaining health protocols, they still do not give any sanctions for activities related to worship. As an alternative, through the TNI (Koramil) and Polri (Sectoral Police), the Government provides counseling programs and socialization of health protocols to the BKM (Badan Kemakmuran Masjid or mosque administrator). Procurement of hand sanitizers, distribution of masks, and spraying disinfectants to mosques are also carried out periodically to maintain the cleanliness and comfort of the congregation when performing worship. In addition, the worshipers are requested to provide their own prayer mats to avoid the use of carpets. .8

\section{c. Wearing Masks in Prayers}

Wearing a mask aims to avoid any dust, odor, or other purposes. During the Covid-19 period, in order to avoid transmission of the virus, people were advised to wear masks, especially clinical masks, so that water droplets as a means of transmitting the virus do not enter their mouth and nose. To campaign the use of masks, the local Government has promoted it through various advertisements, i.e., mass media, electronic media, and banners displayed in almost all corners of the villages in the Aceh region. This attempt is to ascertain that all citizens know about the recommendations for the use of masks, especially when they are outside of their homes to carry out daily activities.

The rule for wearing masks, in fact, should not be a specific issue to discuss because it is something very reasonable and logical that everybody can simply agree and accept without further thinking or rejection. However, the problem arises when someone prays in a congregation at a mosque or meunasah (small mosque in Aceh). People start to question whether religion allows the use of masks considering that it can cover nose when performing sujud (prostration), one of the obligatory moves in the prayer. They also ponder whether using masks can disrupt the implementation of prayers by either eliminating the virtue of prayers or even making it invalid due to covering the face when doing sujud.

The above understanding relates closely to the literal meaning of a hadith of the Prophet, which reads:

${ }^{58}$ Observation result, around Januari-Agustus 2021 


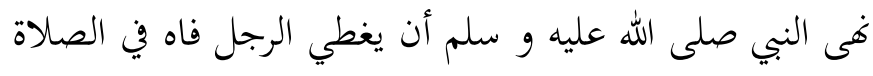

The Prophet forbids men to cover their mouths while praying. ${ }^{59}$

The ulemas explain that covering one's mouth without any need while doing prayers is makruh, but it does not invalidate a prayer. ${ }^{60}$ To this end, in pandemic conditions where the virus can threaten a person's life, wearing a mask to protect oneself in prayers is certainly allowed.61 The phenomenon in Acehnese society has shown two groups of people in responding to this problem. In urban areas, it was found that some worshipers use masks in congregational prayers, but the numbers were not many. In contrast, people in the rural areas were hardly found wearing masks when praying in the congregation. They even did not seem to care about this suggestion both when praying and even when in a crowd. If there were people who wore masks in prayers, they would be judged to have a lack of understanding about religion and unnecessary fear in dealing with Covid-19.

In addition, for some Acehnese, a mosque is a place that is considered quite safe, comfortable, and clean. Moreover, worshippers must have previously purified through wudu (ablution). The purification process in performing $w u d u$ is considered to exceed the standards recommended by the Government with only washing hands, whereas in wudu, the face, hands, and even feet are also purified so that being close to other worshipers is not considered worrisome. In addition, the space of mosques in Aceh is mostly open for enabling air circulation to run well and negating any air sediment that endangers worshipers.

\section{Covid-19 and the Changes on Practices of Prayers in the Perspective of Maqasid al-Shari'a}

Covid-19 as a social phenomenon posing a threat to society has been responded to in several ways. People of Aceh interpret

\footnotetext{
${ }^{59} \mathrm{Abu}$ Abdullah Muhammad bin Yazdi Al-Quzwayni, Sunan Ibn Majah, Volume I (Beirut: Dar Ihya' al-Kutub al-'Arabiyyah, n.d,).

${ }^{60} \mathrm{Abu}$ Zakaria Yahya bin Syarf al-Nawawi, Al-Majmu' Syarh AlMuhadhdhab, Jilid 3.

61Syandri dan Fadlan Akbar.
} 
Covid-19 differently from other regional communities in Indonesia due to their religiosity. Several studies have shown that the public lacks trust in Covid-19, even judges this virus as a farce or conspiracy. ${ }^{62}$ While several places in the country have implemented social distancing, until early 2021, Aceh people still lived as usual. The assumption that Covid-19 is a farce does not only come among Muslims but also Christians who believe that the Covid-19 issue is engineered to keep the congregation away from the church. ${ }^{63}$ In addition, there is also a growing debate that this Pandemic is a conspiracy aiming at disrupting the world's economic order. 64

The belief that life and death are all arranged by Allah ${ }^{65}$ is deeply rooted in Acehnese society as depicted in a popular saying in the Acehnese (Hadih Maja) which reads, "Hak sikai hanjuet si cupak, beurangkaho tajak dumnan syit kada." The saying implies that if Allah has determined something for someone, then wherever he/she goes, that fate will not change. The proverb in a religious view can be interpreted that Allah's destiny (taqdir) will not change if Allah wills. This belief is what makes some Acehnesse ignore health protocols when they respond to Covid-19, and thus, some people do not heed various regulations issued by the Government.

Concerning this matter, Moch. Fajarul Falah emphasized that in the early period of the Covid-19 Pandemic, some people were really afraid of the Covid-19 Pandemic and several mosques in Aceh arranged rows in a distance because they received terrible information, such as seeing videos of people dying in the middle of the road in China. The propaganda made by the media is even more

${ }^{62}$ Y.A. Anjar, Aceh dalam Pandemi: Antara Rasialisme dan Ketidakpatuhan. In W. U. Arifah Rahmawati (Ed.), Kekerasan di Masa Pandemi, Yogyakarta: Fakultas Ilmu Budaya Universitas Gadjah Mada, 2021.

${ }^{63}$ Djone Georges Nicolas, 'Analisis Anggapan Rekayasa Di Balik Pandemi Covid-19, Vaksin Covid-19 Berkaitan Dengan Microchip 666 Dan Antikristus', Jurnal Revolusi Indonesia, 1, No. 3 (2021), 173-180.

${ }^{64} \mathrm{H}$. Nursatyo, 'Pertarungan Wacana Pemerintah Dan Publik Tentang Pandemi Covid-19', Jurnal Penelitian Sosial Ilmu Komunikasi, 5, No. 1 (2021), 37-45.

${ }^{65}$ Ika Amalia, Ella Suzanna dan Liza Adyani, 'Peran Religiusitas Bagi Masyarakat Dalam Menghadapi Pandemi Covid-19', Jurnal Diversita, 7, No. 1 (2021), 79-84. 
terrible. However, as Aceh was one of the latter areas infected by the Covid-19, most Acehnese people were still not sure about the virus when other areas, such as Jakarta, had applied closures of several public places, including worship houses. Many Acehnese still did not care because thinking that the information about this virus implied a hidden mission to keep people away from their religions. It makes very much sense to find them not paying attention to the Government's appeals. ${ }^{66}$

Furthermore, it is understandable to find some people who do not strictly follow the Government's advice. One main reason is that Aceh is among the last areas impacted by the Covid-19 virus outbreak, in addition to the low-density level in Aceh of around 5.3 million people. ${ }^{67}$ In contrast, other places in Java, such as West Java (49.5 million), East Java (40.5 million), Central Java (36.5 million), Banten (11.8 million), and Jakarta (10.5 million) ${ }^{68}$ with high-density levels, have become the epicenter of virus spread. As a result, the Acehnese people feel that the disease they cope with is not as severe as what has happened on the island of Java.

In a similar vein, Bustami, The Head of the BKM of the Sabilil Jannah Mosque in Banda Aceh City, described that geographically, only a small proportion of people in urban areas comply with health protocols when compared to people in rural areas. Furthermore, because the mobility of residents in urban areas is much higher along with many people who travel to and from outside the area, the level of concern in interacting with fellow residents goes the same. On the other hand, those who live in rural areas seem never to worry about

\footnotetext{
${ }^{66}$ Interview with Moch. Fajarul Falah, Member of Aceh MPU, August 3, 2021

${ }^{67 h t t p s: / / a c e h . b p s . g o . i d / i n d i c a t o r / 12 / 55 / 1 / j u m l a h-~ p e n d u d u k . ~ h t m l, ~}$ accessed on October 7, 2021.

${ }^{68}$ https://jabar.bps.go.id/indicator/12/133/1/jumlah-pendudukmenurut-kabupatenkota.html,https://jateng.bps.go.id/statictable/ 2021/04/08/2226/jumlah-penduduk-di-provinsi-jawa-tengah-2020.html, https://jatim.bps.go.id/indicator/12 /375/1/jumlah-penduduk-provinsijawa-timur.html,https://banten.bps.go.id/ indicator/12/46/1/pendudukprovinsi-banten.html,https://jakarta.bps.go.id/ indicator/12/111/1/ jumlah-penduduk-provinsi-dki-jakarta.html, diakses tanggal, 7 Oktober, 2021.
} 
the virus because their mobility is only around their own area as they rarely travel outside. ${ }^{69}$

Another relevant factor is the impression that the Aceh government was late in embracing the ulemas to provide education and information to the public about the dangers of Covid-19 and the need for vigilance against it. In fact, as socially religious people, Acehnese are quite fanatical about ulemas as religious leaders or Tengku that makes them an influential factor in the success of the Government's policies. ${ }^{70}$ For the Acehnese, ulamas are a central figure to follow as they are put as good examples by making their knowledge and morals as the community guides in carrying out any activities in daily life. ${ }^{71}$ In the context of the Pandemic, Achenesse tends to consider ulemas as the objective figures who have no interests. Therefore, their advice and appeals through the mosque and the meunasahs pulpits are more accepted by the community. When the Aceh government has finally realized the situation, several charismatic ulemas had been invited to provide information about the dangers of Covid-19, including several big dayahs (traditional Islamic boarding schools) in Aceh.

This is in line with the comments of Muhajir Al Fairusy, an academic from the Institute for Islamic Studies of Teungku Dirundeng Meulaboh, West Aceh. He explained that the religious practices of the Acehnese people are largely influenced by the understanding of dayahs. The people of Aceh are quite obedient to the fatwas, and advice is given by the ulemas and tengku from Dayah. Indeed, he added, this situation is in accordance with the social system and religious order in Aceh, which is still strong in obeying the advice of the ulemas. ${ }^{72}$

${ }^{69}$ Interview with Bustami, Head of BKM of Sabilil Jannah Mosque, Banda Aceh, August 12, 2021.

70 Abidin Nurdin, 'Reposisi Peran Ulama Dalam Penerapan Syariat Islam Diaceh', Al-Qalam, 18.1 (2016), 54.

${ }^{71}$ Furqan Amri dan Bukhari Ali Salman Abdul Muthalib, 'Practices of the I'adah Zuhur after Friday Prayers in Aceh Besar District: An Analysis with The Perspectives of Islamic Law Approaches', Samarah, 5, No. 1 (2021), 338-356.

${ }^{72}$ Interview with Muhajir al-Fairusy, Lecturer of STAIN Teungku Dirundeng, Meulaboh, August 10, 2021 
In addition, public compliance with the government policies to always maintain health protocols, including in the implementation of worship, is in fact, an obligation because obedience to leaders in Islam covers various problems that arise in society. ${ }^{73}$ Islam is a teaching that not only regulates the relationship between humans and God but also regulates the relationship between humans and their environment. ${ }^{74}$ Moreover, regarding conditions and circumstances that can endanger human lives, such as the Covid-19 case, Islamic law has its own concept called the rules of figh of qa'idah fiqhiyyah. Some of those relevant as efforts to keep away from harm are as follow:

$$
\text { لا ضرر و لا ضار }
$$

Meaning: There should be neither harming nor

reciprocating harm

$$
\text { درء المفاسد مقدم علي جلب المصالح }
$$

Meaning: Warding off evil takes precedence over bringing

benefits

$$
\text { الضرورات تبيح المخظورات }
$$

Meaning: Dire necessities permit prohibitions

The aforementioned rules are considered sufficient to explain that not performing congregational prayers at a mosque is not a part of any legal problem. Moreover, the order to pray at home is a recommendation instead of an obligation. Likewise, it is a recommendation to have a distant row and to wear a mask when praying. Therefore, if someone is unwell or be in a situation in the midst of a virus outbreak that cannot be detected by the naked eye

${ }^{73}$ Analiansyah.

${ }^{74}$ Manna Khalil Al-Qattan, Al-Tasyri' Wa Al-Figh Fi Al-Islam: Tarikhan Wa Manhajan. p.10.

${ }^{75}$ Zayn al-'Abidin ibn Ibrahim ibn Nujaym, Al-Asybah Wa Al-Naza'ir, Jilid 1 (Beirut: Dar al-Kutub al-Ilmiyyah, 1980). 
while the possibility of transmission is very large, praying at home with family is deemed better than in congregation at mosques. ${ }^{76}$

The controversy of performing prayers in Acehnese during the current Pandemic is, therefore, a common thing. Moreover, the government policies apply for all regions in Indonesia no matter each of them deals with different situations and dan danger levels. Some areas coped with the high number of infections, such as Java, parts of Sumatra, Sulawesi, and Bali. However, in Aceh, the number of Covid19 infections and fatality is relatively low compared to the areas mentioned above. Fortunately, later, the Government issued detailed and complete arrangements through the Implementation of Community Activity Restrictions (PPKM) based on the Instruction of the Minister of Home Affairs in July 2021 due to each situation. In these regulations, there are four levels. At areas identified with levels 1 and 2, places of worship may be opened for 50 percent capacity at maximum, while at level 3 areas, the allowed number is only 25 percent, and at the level 4 area, the houses of worship are prohibited from opening. ${ }^{77}$ Since the issuance of the regulations in July 2021, the implementation of worship is relatively in order because differences in the level and the color of each area matter, such as red, orange, yellow, and green. This is an advanced improvement considering that the arrangements in the early period of the spread of Covid-19 had not been regulated explicitly, including the rules for the places of worship.

To this end, the government policies are indeed relevant to one of maqasid al-shari'a points, namely the protection of life (hifz al-nafs) by avoiding contact with the virus. This is particularly because the policies implied benefits that aim to avoid any harm and reject the danger. ${ }^{78}$ Nevertheless, some communities, especially in the districts

${ }^{76}$ Yusran M. Hasibuan, E. M., 'Hukum Shalat Berjamaah Di Masjid Dengan Saf Terpisah Karena Wabah Covid-19', Bustanul Fuqaha: Jurnal Bidang Hukum Islam, 2020, 106-24.

${ }^{77 h t t p s: / / w w w . k o m p a s . c o m / t r e n / r e a d / 2021 / 07 / 31 / 150000165 / i n i-~}$ perbedaan-aturan-ppkm-level-1-2-3-dan-4, accessed on October 8, 2021

78 Y.A. Anjar, Aceh dalam Pandemi: Antara Rasialisme dan Ketidakpatuhan. In W. U. Arifah Rahmawati (Ed.), Kekerasan di Masa Pandemi, Yogyakarta: Fakultas Ilmu Budaya Universitas Gadjah Mada, 2021. 
with low transmission rates, think that congregational prayers at mosques must still be carried out with consideration of maintaining religion (hifz al-din) along with their willingness to comply with health protocols.

\section{Conclusion}

This study concludes that the change of worship in Aceh, particularly the congregational prayer during the Pandemic, is because in the early days of the Covid-19 outbreak until mid-2020, the government policies on PSBB were not perfectly stipulated until the PPKM rules were issued in July 2021 followed by the MUI Fatwa and Aceh Ulama Tausyiah (MPU). The new style of worship practices due to Covid-19 is a common thing in Islamic law perspective because it is considered as a form of maslahah with rukhsah while avoiding harm. Furthermore, policies for not allowing congregational prayers at mosques when the transmission numbers are high refer to maqasid al-shari'a in terms of hifz al-nafs so that people do not get infected by the virus and therefore can save their life. This study recommends that the central and local governments engage the key social figures in promoting the rule through, for instance, cooperating with religious institutions such as MUI and other mass organizations such as NU and Muhammadiyah. The involvement can help people to have far-sighted so that they do not easily believe any unreliable news.

\section{Bilbliography}

Abdul Karim Al-Rafi'i, Al-'Aziz Syarh Al-Wajiz, Vol. II (1st Ed.) (Beirut: Dar al-Kutub al-Ilmiyyah, 1977)

Abdul Wahab al-Khallaf, Ilmu Ushul Figh (12th Ed.) (Kuwait: Dar alQalam, 1978)

Abu Abdullah Muhammad bin Yazdi Al-Quzwayni, Sunan Ibn Majah, Volume I (Beirut: Dar Ihya' al-Kutub al-'Arabiyyah, n.d,)

Abu Zakaria Yahya bin Syarf al-Nawawi, Al-Majmu' Syarh AlMuhadhdhab, Jilid 3.

- - , Al-Majmu' Syarh Al-Muhadhdhab, Jilid IV, (Dar al-Fikr, n.d.)

- - - Al-Majmu' Syarh Al-Muhadhdhab, Jilid IV (Dar al-Fikr, n.d)

Adib Hamzawi, 'Qawa'id Usuliyyah \& Qawa'id Fiqhiyyah (Melacak Konstruksi Metodologi Istinbath Al-Ahkam)', Inovatif, 2, No. 2 
(2016).

Al-Bukhari, Muhammad ibn Ismail, Sahih Al-Bukhari, Vol. 6. (Beirut: Dar Ibn Katsir, 1987)

Al-Zuhayli, Wahbah, Usul Al-Figh Al-Islami, Juz 2, 2nd edn (Damaskus: Dar al-Fikr, 2004)

- - - , Usul Al-Figh Al-Islami, Juz 2 (2nd Ed.) (Damaskus: Dar al-Fikr, 2004)

Ali Hasballah, Usul Al-Tasyri' Al-Islami (Cairo: Dar al-Ma'arif)

Ali, Zainuddin, Metode Penelitian Hukum (Jakarta: Sinar Grafika, 2014)

Analiansyah, 'Ulil Amri Dan Kekuatan Produk Hukumnya (Kajian Terhadap Perspektif Teungku Dayah Salafi Aceh Besar).', Analisa, 21, No. 2 (2014).

Asrorun Ni'am Sholeh, 'Toward a Progressive Fatwa: MUI's Response to the Covid-19 Pandemic', Ahkam, 20, No. 2 (2020.

Asrorun Ni' am Sholeh and Muhammad Ishar Helmi, 'The Covid-19 Vaccination: Realization on Halal Vaccines for Benefits', Samarah, 5, No. 1 (2021).

Ayi Yunus Rusyana, Dedi Supriyadi, Ali Khosim, Fahmi Hasan Nugroho, 'Fatwa Penyelenggaran Ibadah Di Saat Pandemi Covid-19 Di Indonesia Dan Mesir', Digital Library UIN Sunan Gunung Djati, 2020.

Bay, Kaizal, 'Pengertian Ulil Amri Dalam Al-Qur'an Dan Implementasinya Dalam Masyarakat Muslim', Jurnal Ushuluddin, 7, No. 1 (2011).

Djone Georges Nicolas, 'Analisis Anggapan Rekayasa Di Balik Pandemi Covid-19, Vaksin Covid-19 Berkaitan Dengan Microchip 666 Dan Antikristus', Jurnal Revolusi Indonesia, 1, No. 3 (2021).

H. Nursatyo, 'Pertarungan Wacana Pemerintah Dan Publik Tentang Pandemi Covid-19', Jurnal Penelitian Sosial Ilmu Komunikasi, 5, No. 1 (2021).

Hasibuan, E. M., Yusran M., 'Hukum Shalat Berjamaah Di Masjid Dengan Saf Terpisah Karena Wabah Covid-19', Bustanul Fuqaha: Jurnal Bidang Hukum Islam, 2020.

Hendra Gunawan, 'Karakteristik Hukum Islam.', Jurnal Al-Maqasid, 4, No. 2, (2018).

Hudzaifah Achmad Qotadah, 'Covid-19: Tinjauan Maqasid AlShariah Terhadap Penangguhan Pelaksanaan Ibadah Shalat Di 
Tempat Ibadah (Hifdz Al-Nafs Lebih Utama Dari Hifdz AlDin?)', Salam: Jurnal Sosial \& Budaya Syar-I, 7, No. 7 (2020).

Ika Amalia, Ella Suzanna dan Liza Adyani, 'Peran Religiusitas Bagi Masyarakat Dalam Menghadapi Pandemi Covid-19', Jurnal Diversita, 7, No. 1 (2021).

Imam Fahrudin, 'Pengguguran Kewajiban Shalat Berjama'ah Sebagai Upaya Pencegahan Penyebaran Covid-19', SALAM: Jurnal Sosial $\mathcal{E}$ Budaya Syar-I, 7, No. 10, (2020).

'Interview with Fauzi Saleh, Member of Banda Aceh MPU' $<$ https://covid19.acehprov.go.id.>

Jonaedi Efendi and Johnny Ibrahim, Metode Penelitian Hukum: Normatif Dan Empiris (Jakarta: Kencana, 2016)

Juhaya S. Praja, Teori Hukum Dan Aplikasinya (Bandung: Pustaka Setia, 2014)

Jujun Junaedi, Mukhlis Aliyudin, Dede Sutisna, Prita Priantini NC., 'Konflik Interpretasi Fatwa MUI Dalam Pelaksanaan Ibadah Selama Pandemi Covid-19', Al-Tadabbur: Jurnal Kajian Sosial, Peradaban Dan Agama, 6, No. 2, (2020).

Khairunnas Jamal and Kadarusman., 'Terminologi Pemimpin Dalam Alqur'an (Studi Analisis Makna Ulil Amri Dalam Kajian Tafsir Tematik)', An-Nida': Jurnal Pemikiran Islam, 39, No. 1 (2014), 127

Mahmud Syaltut, Al-Islam 'Aqidah Wa Syari'ah (3rd Ed). (Dar alQalam, 1996)

Mahmudin, 'Rukhsah (Keringanan) Bagi Orang Sakit Dalam Perspektif Hukum Islam', Jurnal Ilmiah Al Qalam, 11 (23) (2017).

Manna Khalil Al-Qattan, Al-Tasyri' Wa Al-Figh Fi Al-Islam: Tarikhan Wa Manhajan. , 1976, p. 10. (Maktabah Wahbah, 1976)

- - - Al-Tasyri'Wa Al-Fiqh Fi Al-Islam: Tarikhan Wa Manhajan

Muhammad Arsad Nasution, 'Efektivitas Rukhshah Dalam Pelaksanaan Ibadah Masa Pandemi Covid-19', Yurisprudentia: Jurnal Hukum Ekonomi, 6, No. 1 (2020).

Muhammad bin Idris Al-Syafi'i, Al-Umm Vol. 1 (Beirut: Dar alMa'rifah, 1973)

Muhammad ibn Ismail al-Bukhari, Sahih Al-Bukhari, Vol. 1

Muhammad Kumaidi and Evi Febriani, 'Implementasi Kaidah La Yunkiru Tagayyur Al-Ahkam Bitagayyur Al-Azman Wa AlAhwal Dalam Ibadah Di Masa Pandemi', Asas: Jurnal Politik, Hukum Dan Ekonomi Islam, 12 (1) (2020). 
Nurdin, Abidin, 'Reposisi Peran Ulama Dalam Penerapan Syariat Islam Diaceh', Al-Qalam, $18.1 \quad$ (2016), 54 <https:// doi.org/10.31969/alq.v18i1.244>

S. Samsuduha, 'Masalah Kebijakan Pencegahan Wabah Pandemi Covid-19 Dalam Islam', Jurnal Al-Tafaqquh, 1, No. 2 (2020).

Salman Abdul Muthalib, Furqan Amri dan Bukhari Ali, 'Practices of the I'adah Zuhur after Friday Prayers in Aceh Besar District: An Analysis with The Perspectives of Islamic Law Approaches', Samarah, 5, No. 1 (2021).

Shubhan Shodiq, 'Penanganan Covid-19 Dalam Pendekatan Fikih Dan Ushul Fikih: Analisis Kebijakan Pembatasan Sosial Berskala Besar Di Bidang Keagamaan', Al-Adalah, 5, (2) (2020), 113-34

Sirajuddin, Kasjim Salenda, dan Abdul Wahid Haddade, 'Peniadaan Salat Jumat Dalam Surat Edaran Gubernur Sulsel Nomor: 451.11/2057/2020 Selama Pandemi Covid-19 Perspektif Maqāṣid AlSyarīah,"', NUKHBATUL 'ULUM: Jurnal Bidang Kajian Islam, 6 no. 2 (2020).

Sulaiman Kurdi, Jumratul Mubibah and Ummul Faizah, 'Konsep Taat Kepada Pemimpin (Ulil Amri) Di Dalam Surah an-Nisa : 59, AlAnfal :46 Dan Al-Maidah: 48-49 (Analisis Tafsir Al-Qurthubi, Al-Mishbah, Dan Ibnu Katsir', Journal of Islamic Law and Studies, 1, No. 1 (2017).

Srimulyani, Eka. "Indonesian Muslim Diaspora in Contemporary South Korea: Living as Religious Minority Group in Non-Muslim Country." Samarah: Jurnal Hukum Keluarga Dan Hukum Islam 5, no. 2 (December 26, 2021): 668. https://doi.org/10.22373/sjhk.v5i2.9733.

Syandri dan Fadlan Akbar, 'Penggunaan Masker Penutup Wajah Saat Shalat Sebagai Langkah Pencegahan Wabah Coronavirus Covid19.', Salam: Jurnal Sosial \& Budaya Syar-I, 7, No. 3 (2020), 261-268

Thahir Ibn 'Asyur, Maqasid Al-Syari'ah Al-Islamiyyah (1st Ed.) (Tunisia: Al-Faniyyah)

Zakariya Ali Yusuf Al-Syirazi, Al-Muhadhdhab Fi Figh Al-Imam AlSyafi'i (Beirut: Dar al-Ma'rifah)

Zayn al-'Abidin ibn Ibrahim ibn Nujaym, Al-Asybah Wa Al-Naza'ir, Jilid 1 (Beirut: Dar al-Kutub al-Ilmiyyah, 1980) 


\section{Interviews}

Interview with Mohd. Fajarul Falah (Member of Aceh MPU), on August 3, 2021

Interview with Fauzi Saleh (Member of Banda Aceh MPU) on August 5,2021

Interview with Muhajir Al-Fairusy (Lecturer of STAIN Teungku Dirungden Meulaboh) on August 10, 2021

Interview with Bustami (Head of BKM of Sabilil Jannah Mosque, Banda Aceh City) on August 12, 2021

Interview with Abdullah, member of congregational prayer at a mosque in Dayah Tanoh, Pidie District on August 10, 2021

Interview with Syukur Gade, a local of Banda Aceh City, August 12, 2021.

Interview with Syakirin, a local of Gampong Doy in Banda Aceh City on August 12, 2021 